\title{
Xg Blood Groups of 78 Patients with Klinefelter's Syndrome and of Some of their Parents
}

\author{
A. FRøLAND, RUTH SANGER, and R. R. RACE \\ From the Institute of Medical Genetics, Copenhagen, and the Medical Research Council Blood Group Research Unit, \\ The Lister Institute, London S.W.I
}

$\mathrm{X}$-linked characters, such as the $\mathrm{Xg}$ blood groups (Mann et al., 1962), can sometimes trace the origin of the $\mathrm{X}$ chromosomes in patients with too many or too few of them. Lindsten et al. (1963) applied Xg to a series of patients with Turner's syndrome with a 45,XO karyotype, as did Frøland et al. (1963) and Ferguson-Smith et al. (1964) to some cases of Klinefelter's syndrome. In this paper similar observations on a series of Danish patients with Klinefelter's syndrome are reported.

\section{Subjects and Methods}

The propositi are 78 males with sex chromosome abnormalities whose karyotypes were all determined by one of us (A.F.): 70 of the patients were referred because of endocrinological complaints, such as gynaecomastia, sterility, and hypogonadism. The remainder were found during sex chromatin screening of various groups of patients. The ages of the patients varied from 1 to 80 years; most of them were between 15 and 45.

In 41 patients chromosome studies were done on cultured blood cells only (Moorhead et al., 1960), in 6 on fibroblast cultures only (Frøland, 1961), and in 31 both types of cell were cultured. Generally not less than 50 cells were examined from each culture.

All the patients had a normal number of autosomes. The sex chromosome complements were as follows: XXY: 68 patients, including a pair of monozygotic twins; XXXY: 2 patients; $X X X X Y$ : 4 patients; $\mathrm{XX}: 2$ patients; $\mathrm{XY} / \mathrm{XXY}$ : 1 patient ; and $\mathrm{XY} / \mathrm{XX} / \mathrm{XXY}$ : 1 patient.

The Xg groups were done at the M.R.C. Blood Group Research Unit. The tests included both parents of 30 propositi, the father only of 4 , the mother only of 12 , and neither parent of $32 ; 19$ other relatives were also tested.

The family relationships were checked by a number of autosomal blood groups (ABO, Rh, P, Lewis, Kell, and Duffy); these tests were usually done at the Statens Seruminstitut but sometimes by Dr. Mogens Hauge or at

Received November 20, 1967. the Institute of Forensic Medicine, all in Copenhagen; haptoglobin tests were done by one of us (A.F.).

\section{Results}

Six of the present patients have already been briefly reported (four by Frøland et al., 1963, and two by Lewis et al., 1964). Cytogenetical, endocrinological, and clinical investigations, as well as blood group tests, on 41 of the patients will be described in detail (Frøland, 1968). The Xg groups of relatives other than parents are not included in the present report for they give no additional information.

XXY Propositi. In Table I the distribution of the $\mathrm{Xg}$ groups in $\mathrm{XXY}$ patients and their parents is set out. Ten families give information about the parental origin of the $\mathrm{X}$ chromosomes of the patients.

(1) In two families the fathers and the Klinefelter sons are $\mathbf{X g}(\mathrm{a}+)$ and the mothers are $\mathbf{X g}\left(\mathrm{a}_{-}\right)$, so the patients must have received an $X g^{a}$ gene, and therefore an $\mathrm{X}$ chromosome, from their fathers. This means non-disjunction had happened during spermatogenesis, with the production of an XY bearing spermatozoon. The formula for such persons is $\mathrm{X}^{\mathrm{M}} \mathrm{X}^{\mathrm{P} Y}$ (the superscript $M$ indicating a maternal and $\mathrm{P}$ a paternal origin of the $\mathrm{X}$ chromosome). In two families the fathers are dead but the mothers are $\mathrm{Xg}(\mathrm{a}-)$ and their $\mathrm{XXY}$ sons are $\mathrm{Xg}(\mathrm{a}+)$ : again this means that the sons have received an $\mathrm{X}$ chromosome from their father, who must have been $\mathrm{Xg}(\mathrm{a}+)$. Thus, four $\mathrm{X}^{\mathrm{M}} \mathbf{X}^{\mathrm{P} Y}$ persons were demonstrated.

(2) Three other XXY propositi also have $\mathrm{Xg}(\mathrm{a}+)$ fathers and $\mathrm{Xg}(\mathrm{a}-)$ mothers, but the patients are $\mathrm{Xg}(\mathrm{a}-)$ and cannot have received an $\mathrm{X}$ chromosome from their fathers. Patients having two maternal $\mathrm{X}$ chromosomes are designated $\mathrm{X}^{M} \mathrm{X}^{M} \mathrm{Y}$. The mothers of two $\mathrm{Xg}(\mathrm{a}-)$ patients are dead, but the fathers are $\mathrm{Xg}(\mathrm{a}+)$. Again the 
TABLE I

Xg GROUPS OF 67 XXY KLINEFELTER PATIENTS* AND OF SOME OF THEIR PARENTS

\begin{tabular}{|c|c|c|c|c|}
\hline \multicolumn{2}{|c|}{ Mating Type } & \multicolumn{2}{|c|}{ Patients } & \multirow{2}{*}{ Total } \\
\hline Father & Mother & $\mathbf{X g}_{\mathbf{g}}(\mathbf{a}+)$ & $X_{g}(a-)$ & \\
\hline \multirow[t]{2}{*}{$\begin{array}{c}\mathbf{X g}(\mathbf{a}+) \\
\mathbf{X} \mathbf{g}(\mathbf{a}+) \\
\mathbf{X} \mathbf{g}(\mathbf{a}+) \\
\mathbf{X} \mathbf{g}(\mathbf{a}-) \\
\mathbf{X} \mathbf{g}(\mathbf{a}-) \\
\mathbf{X} \mathbf{g}(\mathbf{a}-) \\
\text { Not tested } \\
\text { Not tested } \\
\text { Not tested } \\
\end{array}$} & \begin{tabular}{|c|}
$\mathbf{X g}(\mathbf{a}+)$ \\
$\mathbf{X g}(\mathbf{a}-)$ \\
Not tested \\
$\mathbf{X g}(\mathbf{a}+)$ \\
$\mathbf{X g}(\mathbf{a}-)$ \\
Not tested \\
$\mathbf{X g}(\mathbf{a}+)$ \\
$\mathbf{X g}(\mathbf{a}-)$ \\
Not tested \\
\end{tabular} & 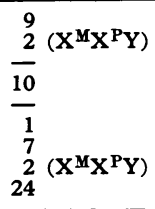 & $\begin{aligned} & 1\left(X^{M_{1}} X^{M_{1}} Y\right) \\
& 3\left(X^{M} X^{M} Y\right) \\
& 2 \star\left(X^{M_{X}^{M} Y}\right) \\
&= \\
&= \\
& \frac{2}{4} \\
&\end{aligned}$ & $\begin{array}{r}10 \\
5 \\
2 \\
10 \\
1 \\
7 \\
4 \\
28\end{array}$ \\
\hline & Total & 55 & 12 & $67 \star$ \\
\hline
\end{tabular}

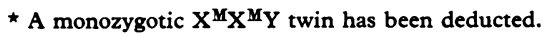

fathers cannot have transmitted an $\mathrm{X}$ chromosome to their sons. So five $\mathrm{X}^{\mathrm{M}} \mathrm{X}^{\mathrm{M}} \mathrm{Y}$ patients were found (the pair of monozygotic twins is counted as one propositus).

(3) In one family both parents are $\mathrm{Xg}(\mathrm{a}+)$, whereas the son is $\mathrm{Xg}(\mathrm{a}-)$. The mother must be heterozygous, $X g^{a} X g$, and her son must have inherited her $X g$ locus in duplo. This can be described by the formula $\mathrm{X}^{\mathrm{M} 1} \mathrm{X}^{\mathrm{M} 1} \mathrm{Y}$ (or $\mathrm{X}^{\mathrm{M} 2} \mathrm{X}^{\mathrm{M} 2} \mathrm{Y}$ ).

Propositi of Other Karyotypes. Table II shows the $\mathrm{Xg}$ groups of Klinefelter patients with other types of sex chromosome anomalies and the groups of some of their parents. The parental groups of one of the four XXXXY patients are informative (previously mentioned by Lewis et al., 1964): the father is $\mathrm{Xg}(\mathrm{a}+)$, the mother $\mathrm{Xg}(\mathrm{a}-)$, and the son $\mathrm{Xg}(\mathrm{a}-)$. Evidently the four $\mathrm{X}$ chromosomes of the son are all of maternal origin.

\section{Discussion}

The abnormal sex chromosome constitutions in Klinefelter's syndrome are produced by non-disjunction, either during spermatogenesis or oogenesis, or at an early cleavage division of the fertilized ovum.

TABLE II

Xg GROUPS OF $10 \mathrm{KLINEFELTER} \mathrm{PATIENTS} \mathrm{WITH}$ KARYOTYPES OTHER THAN XXY, AND OF SOME OF THEIR PARENTS

\begin{tabular}{|c|c|c|c|c|}
\hline Karyotype & $\begin{array}{l}\text { No. of } \\
\text { Patients }\end{array}$ & Father & Mother & Patient \\
\hline $\begin{array}{l}\mathbf{X X X Y} \\
\mathbf{X X X X Y} \\
\mathbf{X X X X Y} \\
\mathbf{X X X X Y} \\
\mathbf{X X} \\
\mathbf{X X} \\
\mathbf{X Y} / \mathbf{X X Y} \\
\mathbf{X Y} / \mathbf{X X} / \mathbf{X X Y}\end{array}$ & $\begin{array}{l}2 \\
1 \\
1 \\
2 \\
1 \\
1 \\
1 \\
1\end{array}$ & $\begin{array}{c}\text { Not tested } \\
\mathbf{X} \mathbf{g}(\mathbf{a}+) \\
\mathbf{X} \mathbf{g}(\mathbf{a}+) \\
\mathbf{X} \mathbf{g}(\mathbf{a}-) \\
\mathbf{X} \mathbf{g}(\mathbf{a}+) \\
\text { Not tested } \\
\text { Not tested } \\
\text { Not tested }\end{array}$ & $\begin{array}{c}\text { Not tested } \\
\mathbf{X g}(\mathbf{a}+) \\
\mathbf{X} \mathbf{g}(\mathbf{a}-) \\
\mathbf{X} \mathbf{g}(\mathbf{a}+) \\
\mathbf{X} \mathbf{g}(\mathbf{a}+) \\
\mathbf{X} \mathbf{g}(\mathbf{a}+) \\
\text { Not tested } \\
\text { Not tested }\end{array}$ & $\begin{array}{l}\mathbf{X} \mathbf{g}(\mathbf{a}+) \\
\mathbf{X} \mathbf{g}(\mathbf{a}+) \\
\mathbf{X} \mathbf{g}(\mathbf{a}-) \\
\mathbf{X} \mathbf{g}(\mathbf{a}+) \\
\mathbf{X}_{\mathbf{g}(\mathbf{a}+)} \\
\mathbf{X} \mathbf{g}(\mathbf{a}+) \\
\mathbf{X}_{\mathbf{g}(\mathbf{a}+)} \\
\mathbf{X} \mathbf{g}(\mathbf{a}+)\end{array}$ \\
\hline
\end{tabular}

(1) $\mathbf{X}^{\mathrm{M}} \mathbf{X}^{\mathrm{P}} \mathbf{Y}$. This formula reflects non-disjunction during spermatogenesis. As the two $\mathrm{X}$ chromatids normally separate from the $\mathrm{Y}$ chromatids during the first meiotic division, the error can be traced to that stage. This mechanism is demonstrated when an XXY son is $\mathrm{Xg}(\mathrm{a}+)$ and the mother is $\mathrm{Xg}(\mathrm{a}-)$.

(2) $\mathbf{X}^{M} \mathbf{X}^{M} \mathbf{Y}$. This formula is less discriminating than $\mathrm{X}^{\mathrm{M}} \mathrm{X}^{\mathrm{P}} \mathrm{Y}$, as it may result from any of several abnormal mechanisms: non-disjunction during the first meiotic division, or non-disjunction during the second meiotic division, or mitotic non-disjunction during an early cleavage division of a normal XY zygote with subsequent loss of YO cells. One or another of these types of maternal origin of the two $\mathrm{X}$ chromosomes is demonstrated when fathers are $\mathrm{Xg}(\mathrm{a}+)$ and $\mathrm{XXY}$ sons are $\mathrm{Xg}(\mathrm{a}-)$.

(3) $\mathbf{X}^{\mathrm{M} 1} \mathbf{X}^{\mathrm{M} 1} \mathbf{Y}$. This formula means that the $X g$ loci of both maternally derived $\mathrm{X}$ chromosomes are identical. It can be produced in the following ways: (a) non-disjunction during the first meiotic division of oogenesis accompanied by crossing-over between the $\mathrm{Xg}$ locus and the centromere; (b) nondisjunction during the second meiotic division without preceding crossing-over; (c) mitotic nondisjunction of an XY zygote. When both parents are $\mathrm{Xg}(\mathrm{a}+)$ and the $\mathrm{XXY}$ son is $\mathrm{Xg}(\mathrm{a}-)$ the $\mathrm{X}^{\mathrm{M} 1} \mathrm{X}^{\mathrm{M} 1} \mathrm{Y}$ type is demonstrated.

(4) $\mathbf{X}^{\mathrm{M}} \mathbf{X}^{\mathrm{M}} \mathbf{X}^{\mathrm{M}} \mathbf{X}^{\mathrm{M}} \mathbf{Y}$. Several explanations are possible: four maternal $\mathrm{X}$ chromosomes could have resulted from two sequent non-disjunctions during oogenesis, or from two sequent mitotic misdivisions, or from a combination of meiotic and mitotic errors. The $\mathrm{X}^{\mathrm{M}} \mathrm{X}^{\mathrm{M}} \mathrm{X}^{\mathrm{M}} \mathrm{X}^{\mathrm{M}} \mathrm{Y}$ type is demonstrated when the patient is $\mathrm{Xg}(\mathrm{a}-)$ and his father $\mathrm{Xg}(\mathrm{a}+)$.

The literature records how the source of the $\mathrm{X}$ chromosome has been determined by the $\mathrm{Xg}$ groups in two other types of sex chromosome anomalies associated with Klinefelter's syndrome as follows.

(5) $\mathbf{X}^{\mathrm{M}} \mathbf{X}^{\mathrm{P} Y Y}$. De la Chapelle et al. (1964b) and Pfeiffer et al. (1966) each record a family in which an $\mathrm{XXYY}$ patient and his father were $\mathrm{Xg}(\mathrm{a}+)$ and the mother $\mathrm{Xg}(\mathrm{a}-)$. The most likely explanation is non-disjunction at the first and the second meiotic division of paternal spermatogenesis, giving rise to an XYY sperm which fertilized a normal ovum. Mitotic misdivision of the $Y$ chromosome in an $\mathrm{X}^{\mathrm{M}} \mathrm{X}^{\mathrm{P} Y}$ zygote is, however, also possible.

(6) $\mathbf{X}^{\mathrm{M}} \mathbf{X}^{\mathrm{M}}$. An apparently normal female karyotype is sometimes found in Klinefelter's syndrome. De la Chapelle et al. (1964a) observed an Xg(a-) phenotype in a patient and his mother. The father was $\mathrm{Xg}(\mathrm{a}+)$. Both $\mathrm{X}$ chromosomes must be of 
maternal origin. A second such family is recorded by De la Chapelle et al. (1965). It is possible that an $\mathrm{X}^{\mathrm{M}} \mathrm{X}^{\mathrm{M}} \mathrm{Y}$ zygote was originally assembled, and that the $\mathrm{Y}$ chromosome was subsequently lost due to mitotic anaphase lagging. There is, however, another possibility which at present seems the more likely. During the past six years the Blood Group Research Unit has been sent samples of blood from $17 \mathrm{XX}$ males whose $\mathrm{Xg}$ distribution fits that expected of males and differs significantly from that expected of people with two Xs ( $p=1$ in 200). If this proves not to be a chance departure it will strongly indicate that $\mathrm{XX}$ males have a single $\mathrm{Xg}$ locus. This would fit well with Ferguson-Smith's (1966) thesis that XX males have one normal X and one $\mathrm{X}$ which carries some genetic material interchanged from a $\mathrm{Y}$ chromosome. (The complementary arrangement, $\mathrm{X}$ material on a $\mathrm{Y}$, has been invoked by Sanger et al., 1964 and by Noades et al., 1966, to explain certain rare families in which the gene for the antigen $\mathrm{Xg}^{a}$ appears to be carried on the Y.)

Of the $67 \mathrm{XXY}$ propositi, 55 are $\mathrm{Xg}(\mathrm{a}+)$ and $12 \mathrm{Xg}(\mathrm{a}-)$. According to Noades et al. (1966), among 67 males of the mainland of northern Europe 40.2 would be expected to be $\mathrm{Xg}(\mathrm{a}+)$ and $26.8 \mathrm{Xg}(\mathrm{a}-)$. The two distributions are significantly different $(p=1$ in 4,000$)$. On the other hand, 67 women would be expected to be divided into $56.3 \mathrm{Xg}(\mathrm{a}+)$ and $10.7 \mathrm{Xg}(\mathrm{a}-)$, which is very close to the distribution found in the patients.

This similarity between the $\mathrm{Xg}$ distribution of the $\mathrm{XXY}$ patients and normal females must mean that the frequency of $\mathrm{X}^{\mathrm{M} 1} \mathrm{X}^{\mathrm{M} 1} \mathrm{Y}$ (or $\mathrm{X}^{\mathrm{M} 2} \mathrm{X}^{\mathrm{M} 2} \mathrm{Y}$ ) is rather low, as the $\mathrm{Xg}$ blood group distribution in such individuals should be that expected of males.

Relative Frequencies of $X^{M} X^{P} Y$ and $X^{M} X^{M} Y$. One of the four possible $\mathrm{Xg}$ mating types is always informative, and this parental combination, $\mathrm{Xg}(\mathrm{a}+)$ father and $\mathrm{Xg}(\mathrm{a}-)$ mother, is found in nearly $10 \%$ of the matings of northern Europeans (Noades et al., 1966): from it the $\mathrm{Xg}(\mathrm{a}+) \mathrm{XXY}$ sons are of the $\mathrm{X}^{\mathrm{M}} \mathrm{X}^{\mathrm{P} Y}$ type and the $\mathrm{Xg}(\mathrm{a}-) \mathrm{XXY}$ sons are $\mathrm{X}^{\mathrm{M} X} \mathrm{X}^{\mathrm{M}} \mathrm{Y}$. The only other combination which is informative is an $\mathrm{Xg}(\mathrm{a}-) \mathrm{XXY}$ son of an $\mathrm{Xg}(\mathrm{a}+)$ father and a heterozygous $\mathrm{Xg}^{a} \mathrm{Xg}$ mother; he is $\mathbf{X}^{\mathbf{M} 2} \mathbf{X}^{\mathbf{M} 2} \mathbf{Y}$.

Mathematical formulae, based on the method of maximum likelihood, have been worked out to estimate, from the $\mathrm{Xg}$ results, the proportion of $X^{M} X^{P} Y, X^{M 1} X^{M 2} Y$, and $X^{M 1} X^{M 1} Y$ plus $X^{M 2} X^{M 2} Y$ (Fraser, 1963). The application of these tests to a series of $190 \mathrm{XXY}$ men and both parents of 50 of them was reported by Edwards et al. (1966); in 7 of these families the $\mathrm{Xg}$ groups had given direct information of the origin of the $\mathrm{X}$ chromosomes. It was calculated that the proportion of $\mathrm{X}^{\mathrm{M}} \mathrm{X}^{\mathrm{P} Y}$ patients was 0.36 , of $\mathrm{X}^{\mathrm{M} 1} \mathrm{X}^{\mathrm{M} 2} \mathrm{Y} 0.42$, and of $\mathrm{X}^{\mathrm{M} 1} \mathrm{X}^{\mathrm{M} 1} \mathrm{Y}$ (or $\mathrm{X}^{\mathrm{M} 2} \mathrm{X}^{\mathrm{M} 2} \mathrm{Y}$ ) 0.22 : these proportions are tentative only, for the mathematical tests require larger numbers.

The proportion of patients with $\mathrm{X}^{\mathrm{M}} \mathrm{X}^{\mathrm{P} Y}$ and $X^{M} X^{M} Y$ constitutions in the present material is four to five, if the four cases are included where the $\mathrm{Xg}$ groups of a missing parent can be deduced from those of the other parent and the patient (see Table I).

\section{Parental Age and Source of X Chromosomes} in Klinefelter's Syndrome. It is generally found that the maternal age at the birth of patients with Klinefelter's syndrome is significantly higher than in the average population (Ferguson-Smith, 1958; Lenz, 1959).

Table III gives the parental ages for those patients in the present series where the $\mathrm{Xg}$ groups have given information about the origin of the $X$ chromosomes: the ages in the class due to paternal non-disjunction do not differ very much from the ages in the class with two maternal X chromosomes.

From official records the average age of 62 fathers at the birth of XXY patients in the present series was 34.9 years and of 64 mothers 31.6 years. It is interesting to note that the average maternal age at the birth of the patients, both in the $\mathrm{X}^{\mathrm{M}} \mathrm{X}^{\mathrm{P} Y}$ class and in the $\mathrm{X}^{\mathrm{M}} \mathrm{X}^{\mathrm{M}} \mathrm{Y}$ class, is closer to that of the Danish population (29.4 years) than to that found in the patient series as a whole. This may be so partly because the number of patients having a

TABLE III

\begin{tabular}{|c|c|c|}
\hline \multicolumn{3}{|c|}{$\begin{array}{l}\text { PARENTAL AGE AT BIRTH OF } \\
11 \text { KLINEFELTER PATIENTS } \\
\text { THE ORIGIN OF WHOSE X } \\
\text { CHROMOSOMES WAS MADE } \\
\text { CLEAR BY Xg GROUPS }\end{array}$} \\
\hline \multirow{2}{*}{ Patient } & \multicolumn{2}{|c|}{ Age at Birth of Patient } \\
\hline & Father & Mother \\
\hline $\begin{array}{l}\mathbf{X}^{\mathbf{M}} \mathbf{X}^{\mathbf{P Y}} \\
\mathbf{X}^{\mathbf{M}} \mathbf{P Y} \\
\mathbf{X}_{\mathbf{M}}^{\mathbf{P} Y} \\
\mathbf{X}^{\mathbf{M}} \mathbf{X}^{\mathbf{P Y}}\end{array}$ & $\begin{array}{l}22 \\
30 \\
44 \\
30\end{array}$ & $\begin{array}{l}16 \\
32 \\
36 \\
27\end{array}$ \\
\hline Mean & $31 \cdot 5$ & $27 \cdot 8$ \\
\hline 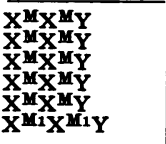 & $\begin{array}{l}39 \\
36 \\
30 \\
32 \\
36 \\
30\end{array}$ & $\begin{array}{l}41 \\
31 \\
19 \\
30 \\
30 \\
27\end{array}$ \\
\hline Mean & $33 \cdot 8$ & $29 \cdot 7$ \\
\hline$\overline{\mathbf{X}^{M} \mathbf{X}^{M} \mathbf{X}^{M} \mathbf{X}^{M Y}}$ & 40 & 32 \\
\hline
\end{tabular}


known origin of the $\mathrm{X}$ chromosomes is rather small, and partly because the probability of the parents being alive, and so available for grouping, is decreasing with increasing parental age. The average age of 39 mothers at the birth of the XXY in the present series was 31.0 years when one or both parents had been tested; when neither parent had been tested the average age of 25 mothers was 32.5 years. The corresponding paternal ages showed no difference: 35.3 years and 34.7 years, respectively, in the two groups.

The possibility of introducing a sampling error of this type demands great caution when estimating the influence of paternal or maternal age on the aetiology of the XXY syndrome, except when the propositi are very young.

\section{Summary}

The Xg blood groups of a series of 78 Danish patients with Klinefelter's syndrome are reported together with those of their available parents. In 11 patients the origin of the $\mathrm{X}$ chromosomes could be traced. In four patients with a 47,XXY karyotype the $\mathrm{X}$ chromosomes were derived from both parents $\left(\mathrm{X}^{\mathrm{M}} \mathrm{X}^{\mathrm{P}} \mathrm{Y}\right)$, showing that the non-disjunction had happened during spermatogenesis. In six patients both $\mathrm{X}$ chromosomes were of maternal origin $\left(\mathrm{X}^{\mathrm{M}} \mathrm{X}^{\mathrm{M}} \mathrm{Y}\right)$, due to non-disjunction either during oogenesis or at an early postzygotic division. In one patient with a $49, \mathrm{XXXXY}$ karyotype all four $\mathrm{X}$ chromosomes were evidently of maternal origin.

\section{REFERENCES}

De la Chapelle, A., Hortling, H., Niemi, M., and Wennström, J. (1964a). XX sex chromosomes in a human male. Acta med. scand., Suppl. 412, 25. di- Sanger, R., and Race, R. R. (1964b). Successive nondisjunction at first and second meiotic division of spermatogenesis: evidence of chromosome and $\mathrm{Xg}$. Cytogenetics, $3,334$.

- Wennström, J., and Johansson, C.-J. (1965). Two $\overparen{\mathbb{D}}$ males with female chromosomes. Acta endocr. (Kbh.), Suppl. 100 , p. 90 , abstract 58 .

Edwards, J. H., Ferguson-Smith, M. A., Frøland, A., Lindsten, J., Polani, P. E., Race, R. R., and Sanger, R. (1966). The contribution of the $\mathbf{X g}$ blood groups to $\mathrm{X}$ chromosome aneuploidy: an interim report. Abstract No. 90, 3rd Int. Congr. Human Genet., $\frac{\sigma}{\bar{\omega}}$
p. 28 .

Ferguson-Smith, M.A. (1958). Chromatin-positive Klinefelter's syndrome (primary microrchidism) in a mental-deficiency hospital. Lancet, 1, 928.

(1966). X-Y chromosomal interchange in the aetiology of true hermaphroditism and of XX Klinefelter's syndrome. ibid., 2, 475. $\overrightarrow{0}$ -, Mack, W. S., Ellis, P. M., Dickson, M., Sanger, R., and Race, R. R. (1964). Parental age and the source of the $X$ chromosomes in XXY Klinefelter's syndrome. ibid., 1, 46.

Fraser, G. R. (1963). Parental origin of the sex chromosomes in the XO and XXY karyotypes in man. Ann. hum. Genet., 26, 297.

Frøland, A. (1961). A simplified method for making chromosome preparations from skin biopsies. Acta path. microbiol. scand., 53, i 319.

- (1968). Klinefelter's syndrome. Thesis. To be published. -, Johnsen, S. G., Andresen, P., Dein, E., Sanger, R., and Race, $\sigma$ R. R. (1963). Non-disjunction and XXY men. Lancet, 2, 1121. Lenz, W. (1959). Der Einfluss des Alters der Eltern und Geburten- 음 nummer auf angeborene pathologische Zustände beim Kind. II. Spezieller Teil. Acta genet. (Basel), 9, 249.

Lewis, F. J. W., Froland, A., Sanger, R., and Race, R. R. (1964). ( Source of the $\mathrm{X}$ chromosomes in two XXXXY males. Lancet, 2, 589.

Lindsten, J., Bowen, P., Lee, C. S. N., McKusick, V. A., Polani, P. E., Wingate, M., Edwards, J. H., Hamper, J., Tippett, P., Sanger, R., and Race, R. R. (1963). Source of the X in XO females: the evidence of $\mathrm{Xg}$. ibid., 1,558 .

Mann, J. D., Cahan, A., Gelb, A. G., Fisher, N., Hamper, Tippett, P., Sanger, R., and Race, R. R. (1962). A sex-linkę blood group. ibid., $1,8$.

Moorhead, P. S., Nowell, P. C., Mellmann, W. J., Battips, D. ME and Hungerford, D. A. (1960). Chromosome preparations leukocytes cultured from human peripheral blood. Exp. Cell Res. 20, 613.

Noades, J., Gavin, J., Tippett, P., Sanger, R., and Race, R. R. (1966). The X-linked group system Xg. Tests on British, northern American and northern European unrelated people and families. f. med. Genet., 3, 162.

Pfeiffer, R. A., Körver, G., Sanger, R., and Race, R. R. (1966) Paternal origin of an XXYY anomaly. Lancet, 1, 1427.

Sanger, R., Race, R. R., Tippett, P., Gavin, J., Hardisty, R. M., and Dubowitz, V. (1964). Unexplained inheritance of the Xg groups in two families. ibid., 1,955 . 